\title{
The Mediating effect of Organizational Learning Capability on High Performance Work System and Corporate Entrepreneurship Relationship
}

\author{
Ramesh Rajagopal
}

\begin{abstract}
Organizations are able to achieve improved performance with the use of technical knowledge and benefits arrived out of the usage of the same. Corporate entrepreneurship relationship and the enhanced performance works together in the current dynamic economic conditions. Increasing learning capabilities for organizations are must without which survival in the market will be questionable. Organizational learning programs will lead to improve the competencies. The requirements of the stakeholders are varying in nature which makes the organizational learning more complex.
\end{abstract}

Keywords - competitive advantage, entrepreneurial activities, entrepreneurship, Organizational learning, .

\section{INTRODUCTION}

$\mathrm{T}$ HE globalization and the challenging business environment is forcing all the companies to keep innovating in their products and services continuously. Combined with this, the technological revolution has created new path in the commercial environment and the way of interaction to the vendors and customers have changed drastically. Introduction of Enterprise Resource Planning (ERP) solutions, integrated solutions which links all the activities of the organization right from procurement, logistics, manufacturing, sales, marketing and finance etc has changed the business processes and the operational methodology. The business environment is changing constantly and rapidly along with the market, suppliers, stake holders and customers' needs [1].

Organizations and managers are forced to learn new technologies and keep them updated of their knowledge base.

PhD Student, Annamalai University, India
Organizations pursue learning in entrepreneurial activities may attain competitive advantage [2] \& [3]. The organizational learning and innovation to their products and services always rely on their capability in learning and creative to respond to the ever changing customer needs and market.

Various definitions have been used to describe entrepreneurship, such as corporate venturing [4], intrapreneurship [5], corporate entrepreneurship [6], internal corporate entrepreneurship [7], and strategic entrepreneurship [8]. Recently, the topic of corporate entrepreneurship has become the research area for many research scholars [9]. The major task of entrepreneurship shall be able to identify the factors which creates customer dissatisfaction and find out various alternatives to mitigate them or eliminate them [10].

Researches show that corporate entrepreneurship can play very important role in achieving higher levels of corporate performance, organizational growth [11], and profitability [12].

Market orientation refers to an organization's capability in collecting the ever changing customers' needs, analyse the same within the organization and react to the market on timely basis [13]. Organizations with strong market orientation focus on learning and innovation from their current market, competitors and their existing customers. Market orientation is always positively associated with firm-level consequences, which includes financial performance and business performance [14].

An organization must do a SWOT analysis to understand their strengths, weaknesses within the organization and opportunities and threats from the market. Also the organization must do a competitor analysis which shall include long-term strategies of current and potential competitors. The result of the analysis can identify new product ideas ahead of the competition. The market-based organizational learning capability is related to changes in customer preferences and competitors' actions [15]. Generating new ideas for products and services through the collection and dissemination of market information is the starting point for developing the innovation process.

We should distinguish between domestic and international venturing [16]. International venturing is related to an 
organization's efforts to identify opportunities outside their home market [17]. Before going to International markets, the company need to excel in their local market as going international is considered to be more difficult than expanding in local market [18]. There are lots of constraints like lack of knowledge of the target market, consumer behavior, business environment etc [19]. International markets might be more competitive than domestic markets considering our additional costs involved in targeting new markets [20].

Despite having lot of challenges in going abroad, globalization has laid a foundation to the interested companies to enter into any newer markets, face the challenges, learn new ideas from the international market which helps to strengthen their overall business both local and international.

Entrepreneurial orientation can be defined as autonomy, innovativeness, pro-activeness, competitive aggressiveness, and risk-taking [21]. An organization has to have willingness in identifying new products and services, concepts and processes with a forward looking and at the same time with a cautious approach. All the above activities should be in line with their corporate strategies and also should provide a competitive edge against their competitors which should be sustainable.

Organizational learning can be defined as the process of acquiring, distributing, integrating, and creating information and knowledge among organizational members [22]. An organization's success can be supported by a knowledge based resource capability which shall lead to innovation [23]. Organizations require all their team members to learn and interpret the PEST (Political, Economic, Social and Technological) analysis [24].

Many organizations are pressured to include the entrepreneurial orientation and organizational learning as part of their strategies so as to generate new business opportunities and maximize shareholder value. Many companies are planning to have a competitive advantage against their competitors. Competitive advantage can be achieved by following an organizational learning strategy which shall involve all executives and team members to be part of it. Competitive advantage can be easily copied by the competitors also. To be in the front of the race, the organizations have to have the learning on a regular basis and the competitive advantage strategy has to be reviewed frequently considering the changes in the market and customer buying pattern.

Any organization that does not focus on continues learning, development and adapting to innovative technology may not be existing and maintain sustainability for a long period. In this scenario, the management strategic decisions play a vital role for organizational effectiveness [25].

It is expected all the executives shall have the capability to learn, process the information, decision making skills and most importantly create a knowledge base which can be used by other team members also. The literature has also connected learning orientation to the principle means of achieving strategic decisions in an organization [26]. Hence, learning orientation is one fundamental source of creating competitive advantage and equated with innovative efficiency [27]. An organization's knowledge is an asset and if managed properly this will contribute to greater innovation and enhance performance [28].

The term innovation and creativity at the individual-level are sometimes used interchangeably [29]. Innovative behavior from the individual point of view can be defined as "an initiative from employees regarding introduction of new processes, new products, new markets or combinations of such into the organization" [30].

Innovation is not to be treated as an individual effort, however it is a collective effort from all the team members. The organization should encourage open discussions within the company and allow everyone to participate and propose their ideas, suggestions, feedback etc and evaluate them carefully. Sometimes the ideas and suggestions can be great however this may not fit into the corporate strategy.

Organizations shall have clear policies and ensure that learning process is a continual one to all the executives and team members and ensure that the knowledge earned through various activities are captured and stored within the organization for the benefit of others as well. There should be clear link between the corporate strategy and the learning programs. The outcome of the learning programs has to be properly reviewed to ensure that they help to improve individual performance which will have positive impact on organizational performance.

\section{REFERENCES}

[1] Prajogo, D. I. \& Ahmed, P. K., "Relationships between innovation stimulus, innovation capacity and innovation performance" in R\&D Management, 2006, pp. 499-515.

[2] Barsh, J , "Innovation Management: A conversation with Gary Hamel and Lowell Bryan", TheMcKinsey Quarterly, 2007, pp. 1-10.

[3] Chapman, R., \& Hyland, P, "Complexity and learning behaviors in product innovation",Technovation, 2004, pp. 553-561. https://doi.org/10.1016/S0166-4972(02)00121-9

[4] Burgelman, R. A. A Process Model of Internal Corporate Venturing in the Diversified Major Firm (1983). Administrative Science Quarterly, 28(2): 223-244.

https://doi.org/10.2307/2392619

[5] Pinchot, G. Intrapreneuring: Why You Don't Have to Leave the Corporation to Become an Entrepreneur, 1985. New York, NY: Harper \& Row.

[6] Guth, W. D., \& Ginsberg, A., Guest Editors' Introduction: Corporate Entrepreneurship (1990). Strategic Management Journal, 11(5), 5-15.

[7] Jones, G. R. \& Butler, J. E., Managing internal corporate entrepreneurship: Agency theory perspective, (1992). Journal of management, 18, 733-749. https://doi.org/10.1177/014920639201800408

[8] Hitt, M. A., Ireland, R. D., Sirmon, D. G., \& Trahms, C. A., Strategic Entrepreneurship: Creating Value for Individuals, Organizations, and Society, 2011. The Academy of Management Perspectives, 25(2), 5775. https://doi.org/10.5465/AMP.2011.61020802

[9] Guth, W. D. and Ginsberg, A. Guest editor's introduction: Corporate entrepreneurship, (1990). Strategic Management Journal, 11, 5-15.

[10] Ramachandran, K., Customer Dissatisfaction as Sources of Entrepreneurial opportunity, (2003). Nanyang Business Review, 2(2), 21-38. 
[11] Yiu, D. W., \& Lau, C. M., Corporate Entrepreneurship as Resource Capital Configuration in Emerging Market Firms, 2008. Entrepreneurship Theory and Practice, 32(1): 37-57. https://doi.org/10.1111/j.1540-6520.2007.00215.x

[12] Covin, J.G. and Miles, P.M., "Corporate Entrepreneurship and the Pursuit of Competitive Advantage", (1999), Entrepreneurship: Theory and Practice, Vol. 23, pp. 47-63

[13] Desphande, R., \& Farley, J. U., Corporate culture and market orientation: Comparing India and Japanese firms, 1999. Journal of International Marketing, 57(1), 111-127.

[14] Jimenez-Jimenez D., Sanz Valle, R., Innovation, organizational learning, and performance", (2011), Journal of Business Research, Vol. 64 , pp. $408-417$ https://doi.org/10.1016/j.jbusres.2010.09.010

[15] Weerawardena, J., "Exploring the role of market learning capability in competitive strategy" (2003), European Journal of Marketing, Vol. 37, No. 3/4, pp. 407-429 https://doi.org/10.1108/03090560310459023

[16] Yiu, D. W., Lau, C. M., \& Bruton, G. D., International Venturing by Emerging Economy Firms: The Effects of Firm Capabilities, Home Country Networks, and Corporate Entrepreneurship, 2007. Journal of International Business Studies, 38(4): 519-540. https://doi.org/10.1057/palgrave.jibs.8400278

[17] Zahra, S. A. and Covin, J. G., Contextual influences on the corporate entrepreneurship-performance relationship: A longitudinal analysis (1995). Journal of Business Venturing, 10, 43-58. https://doi.org/10.1016/0883-9026(94)00004-E

[18] Yiu, D. W., Lau, C. M., \& Bruton, G. D., International Venturing by Emerging Economy Firms: The Effects of Firm Capabilities, Home Country Networks, and Corporate Entrepreneurship, 2007. Journal of International Business Studies, 38(4): 519-540. https://doi.org/10.1057/palgrave.jibs. 8400278

[19] Zaheer, S., Overcoming the Liability of Foreignness, 1995,. Academy of Management Journal, 38(2): 341-363. https://doi.org/10.2307/256683

[20] Etemad, H., \& Wright, R. W., Internationalization of SMEs: Toward a New Paradigm, 2003. Small Business Economics, 20(1): 1-4. https://doi.org/10.1023/A:1020274419262

[21] Lumpkin, G. T., \& Dess, G. G., Clarifying the entrepreneurial orientation construct and linking it to performance, (1996). Academy of Management, 21(1), 135-172.

[22] Dixon, N. M.. Organizational learning: a review of the literature with implications for HRD professionals. Human Resources Development Quarterly, (1992), 3(1), 29-49. https://doi.org/10.1002/hrdq.3920030105

[23] Casey, A., Enhancing individual and organizational learning. Management Learning, 36(2), 131-147. https://doi.org/10.1177/1350507605052555

[24] Birdthistle, N., \& Fleming, P., Creating a learning organization within the family business: An Irish perspective. Journal of European Industrial Training, (2005), 29(9), 730-750. https://doi.org/10.1108/03090590510629858

[25] Merrifield, D. B., Entrepreneurial Corporate Renewal, (1993). Journal of Business Venturing, 8(5), 383-389. https://doi.org/10.1016/0883-9026(93)90020-6

[26] Crossan, M. M., \& Berdrow, I., Organizational learning and strategic renewal (2003). Strategic Management Journal, 24(11), 1087-1105. https://doi.org/10.1002/smj.342

[27] Lopez, S. P., Peon, J. M. M., \& Ordas, C. J. V. (2005). Organizational learning as a determining factor in business performance. The Learning Organization, 12(3), 227-245. https://doi.org/10.1108/09696470510592494

[28] Pham, N. T., \& Swierczek, F. W., Facilitators of organizational learning in design, (2006). The Learning Organization, 13(2), 186-201. https://doi.org/10.1108/09696470610645502

[29] Scott, S. G., \& Bruce, R. A.. Determinants of innovative behavior: A path model of individual innovation in the workplace, (1994). Academy of Management Journal, 37(3), 580-607. https://doi.org/10.2307/256701

[30] Åmo, B. W., \& Kolvereid, L.. Organizational strategy, individual personality and innovation behavior, (2005). Journal of Enterprising Culture, 13(1), 7-19
https://doi.org/10.1142/S0218495805000033 